\title{
FIXED PART OF THE MODEL FOR BREEDING VALUE ESTIMATION IN PIGS BASED ON LITTER SIZE**
}

\author{
D. Radojković ${ }^{1 *}$, M. Petrović ${ }^{2}$, M. Mijatović ${ }^{1}, \check{C}$. $\operatorname{Radović}^{2}$ \\ ${ }^{1}$ Faculty of Agriculture - University of Belgrade, Serbia \\ ${ }^{2}$ Institute for Animal Husbandry Belgrade - Zemun, Serbia \\ * Corresponding author: radodrag@agrifaculty.bg.ac.yu \\ ** Original scientific paper
}

\begin{abstract}
The goal of this paper was to investigate the effect of various fixed effects on the number of born alive piglets in litter (NBA), based on results of Swedish Landrace sow fertility on three farms in Setbia, in order to determine the best adapted model for assessing genetic parameters and breeding value. Analysis of phenotipic variability of the NBA of Swedish Landrace sows was carried out based on fertility results on three swine farms (A, B and C) in the Republic of Serbia. Data sets encompassed reproduction indicators for 2803 (A), 1826 (B) and 2235 (C) sows, i.e. their 11014, 6757 and 8452 litters, respectively. For this analysis was used fix model of least square method which includes fixed effects of farrowing number, season of conception shown as combination of year and month, litter genotype, duration of previous period from weaning to conception, effect of sow age at farrowing like quadratic regression nested within farrowing number and linear regression influence of duration of previous lactation. The average NBA was within the interval from 9.13 (A) to 9.76 piglets (B and C). The monitored trait statistically highly significantly $(p<0.001)$ varied under the effect of all systematic factors encompassed by the applied model, regardless of the source of analyzed data, Only the linear regression effect of duration of previous lactation for farm B was assessed as having lower statistical significance $(\mathrm{p}<0.05)$.
\end{abstract}

Key words: sows, fertility, phenotypic variability

\section{Introduction}

Modern swine breeding programs devote much attention to upgrading fertility traits. Assessment of the breeding value of sows for litter size is 
based on using the mixed model method. This method simultaneously assesses fixed and evaluates random effects for the selected trait. To achieve the highest possible precision when assessing breeding value of sows, it is important to correctly select and define fixed effects on litter size, which is most often described by the number of born alive piglets (NBA). This is especially important due to the fact that the fixed segment of the model predominantly explains a small part of the total variability of this trait.

The number of born alive piglets is influenced by numerous factors, however only some of them can be precisely determined and recorded under production conditions. Effects such as farrowing number, age at farrowing, breeding season, length of previous lactation, or duration of the preceding period from weaning to breeding, are parameters regularly recorded when monitoring sow fertility under all production conditions. Contrary to previously mentioned effects, effects such as manner of housing, nutrition, diseases, or effects of boar are very rarely recorded, even though they influence the variation of number of born alive piglets to a considerable extent.

It is generally known that the NBA in a litter grows for the first few farrowings. Johansson and Kennedy (1985) established that the average NBA piglets was 9.70 for the first, and 11.20 for the third farrowing. The average expression of this trait in the first and the third farrowing was 9.60, i.e. 10.68 piglets, while the established difference was statistcally significant, as shown by Petrovic Milica et al. (1998).

Analyzing a data set containing results obtained for fertility of breeding animals for several years in sequence, Malovrh Spela et al. (1998) established that changes of fertility were not periodic by seasons, but rather in fact had differing directions. As a consequence, authors recommend that, instead of the classic approach of deviding the year into four calendar seasons, when analyzing litter size variability, the interaction between year and month of successful breeding should be used. This enables a significantly higher coefficient of model determination.

Gajic (1989) established significant differences of the NBA between purebred litters and crossbred litters for the first three farrowings of Swedish Landrace sows inseminated by boars of various breeds. A similar approach is used to analize the said effect also by analyzing the effect of boar - litter parent - gentype, which, in the case when females have the same gentype, in fact also means the observation of the effect of litter gentype.

Urankar Janja et al. (2004) and Lukovic (2006) demonstrated a statistically significant variation of the NBA due to the influence of the 
duration of the period from weaning to breeding. These same authors state that for the first two farrowings, litter size increases with sow age at farrowing up to a certain age, and then decreases. In addition, it was established that with age increase within third and later farrowings, changes of litter size are not so dynamic, and can be described by a unique curve. Authors express the opinion that the change of litter size depending on the age of females at farrowing, can best be described by square regression nested within farrowing number, with third and latter farrowings pooled into one class.

The goal of this paper was to investigate the effect of various fixed effects on the number of born alive piglets in litter, based on results of Swedish Landrace sow fertility on three farms in Setbia, in order to determine the best adapted model for assessing genetic parameters and breeding value.

\section{Materials and Methods}

In this investigation, analysis of phenotipic variability of the number of born alive piglets in litter (NBA) of Swedish Landrace sows was carried out based on fertility results on three swine farms (A, B and C) in the Republic of Serbia. Data sets encompassed reproduction indicators for 2803 (A), 1826 (B) and 2235 (C) sows, i.e. their 11014, 6757 and 8452 litters, respectively. There was a strong genetic relationship between animals on farms B and C, enabling evaluation of genetic parameters based on pooled data. In this case, the analyzed data set encompasses 4061 sows and 15209 of their litters.

Phenotypic variability of the NBA was analyzed using the GLM procedure of "SAS/STAT" (SAS Inst. Inc., 2001) programe package, by applying the following fixed model least squares method:

$\left[\begin{array}{l}y_{l i j k l m} \\ y_{2 i j k l m}\end{array}\right]=\mu+P_{i}+S_{j}+G L_{k}+b_{l i}\left(x_{i j k l m}-\bar{x}\right)+b_{2 i}\left(x_{i j k l m}-\bar{x}\right)^{2}+\left[\begin{array}{l}0 \\ Z O_{l}+b_{3}\left(z_{i j k l m}-\bar{z}\right)\end{array}\right]+e_{i j k l m}$

where: $y_{n i j k l m}$ is the expression of the monitored trait of $m$-th individual in litters of first furrowing females $(n=1)$ or older sows $(n=2), \mu$ - general average, $P_{i}$ - fixed effect of farrowing number, $S_{j}$ - fixed effect of season of successful breeding shown as combination of year and month, $G L_{k}$ - fixed effect of litter gentype, $b_{1 i}\left(x_{i j k l m}-\bar{x}\right)$ - linear member of square regression effect of sow age at farrowing $(x)$ nested within farrowing number, $b_{2 i}\left(x_{i j k l m^{-}}\right.$ $\bar{x})^{2}$ - square member of square regression effect of sow age at farrowing $(x)$ 
nested within farrowing number, $Z O_{l}$ - fixed effect of class for duration of previous period from weaning to breeding, $b_{3 i}\left(z_{i j k l m^{-}} \bar{z}\right)$ - linear regression effect of duration of previous lactation and $e_{i j k l m}$ - residue. The model used to analyze composite results for fertility on farms $\mathrm{B}$ and $\mathrm{C}$ also contained the fixed effect of farm $(F)$.

The application of a unique model for analyzing phenotypic variability of the NBA in litters of first furrowing and older sows required special data preparation, due to the fact that for biological reasons, data on the effect of duration of previous period from weaning to fertilization, and effect of duration of previous lactation on the number of born alive piglets do not exist for litters of first farrowing females.

\section{Results and Discussion}

Table 1 contains results of descriptive statistical analysis for the NBA obtained based on the analysis of results of fertility achieved on various farms.

Table 1. Results of descriptive statistical analysis for number of born alive piglets (NBA) by farms

\begin{tabular}{c|cccccc}
\hline Farm & $\mathrm{N}$ & $\bar{X}$ & $\mathrm{SD}$ & $\min$ & $\max$ & $\mathrm{CV}$ \\
\hline $\mathrm{A}$ & 11014 & 9.13 & 2.66 & 0 & 19 & 29.14 \\
$\mathrm{~B}$ & 6757 & 9.76 & 2.78 & 0 & 20 & 28.49 \\
$\mathrm{C}$ & 8452 & 9.76 & 2.89 & 0 & 20 & 29.66 \\
$\mathrm{~B}+\mathrm{C}$ & 15209 & 9.76 & 2.84 & 0 & 20 & 29.15 \\
\hline
\end{tabular}

The average NBA was within the interval from 9.13 (A) to 9.76 piglets (B and C), while the coefficient of variation was from $28.49 \%$ (B) to $29.66 \%$ (C), indicating a somewhat more pronounced phenotypic variability for this trait on investigated farms, since the value for this indicator of variation is most often in the interval between $20 \%$ and $25 \%$.

Established average values for the NBA are in agreement with results obtained by a group of authors, in whose publications the average expression of the investigated trait in several farrowings in sequence was within the demonstrated interval (Petrovic Milica et al., 1998, Logar Betka, 2000, Urankar Janja et al., 2004, and Lukovic, 2006).

Table 2 contains data on statistical significance of various systematic effects on variability of the number of born alive piglets, as well as the number of degrees of freedom, and value for coefficients for model 
determination.

Table 2. Statistical significance of influences (p-values) on variability of number of born alive piglets (NBA), degrees of the freedom (d.f), coefficient of determination and standard deviation of error $\left(\sigma_{\mathrm{e}}\right)$ by farms

\begin{tabular}{|c|c|c|c|c|c|c|c|c|c|c|}
\hline \multirow{2}{*}{ Farm } & \multicolumn{7}{|c|}{ Source of variation ( $\mathrm{p}$-values) } & \multirow{2}{*}{ d.f. } & \multirow{2}{*}{$\mathrm{R}^{2}$} & \multirow{2}{*}{$\sigma_{\mathrm{e}}$} \\
\hline & $P$ & $S$ & $\overline{G L}$ & $Z O$ & $b_{1}$ & $b_{2}$ & $b_{3}$ & & & \\
\hline A & $<.0001$ & $<.0001$ & $<.0001$ & $<.0001$ & $<.0001$ & $<.0001$ & $<.0001$ & 174 & 0.119 & 2.52 \\
\hline B & $<.0001$ & $<.0001$ & $<.0001$ & $<.0001$ & $<.0001$ & $<.0001$ & 0.03 & 165 & & 2.67 \\
\hline $\mathrm{C}$ & $<.0001$ & $<.0001$ & $<.0001$ & $<.0001$ & $<.0001$ & $<.0001$ & $<.0001$ & 177 & 0.104 & 2.77 \\
\hline $\mathrm{B}+\mathrm{C}$ & $<.0001$ & $<.0001$ & $<.0001$ & $<.0001$ & $<.0001$ & $<.0001$ & $<.0001$ & 178 & 0.085 & 2.73 \\
\hline
\end{tabular}

Listed results show that all determined effects encompassed by the model had statistically highly significant effects $(p<0.001)$ on the variation of the NBA, regardless of which data set was analyzed. Only the linear effect of duration of previous lactation $\left(b_{3}\right)$ was evaluated as having a lower level of statistical significance $(\mathrm{p}<0.05)$ when data from farm B was analyzed.

The result obtained for effect of farrowing number $(P)$ on the variation of the NBA is in agreement with results reported by Johansson and Kennedy (1985), Petrovic Milica et al. (1998), Malovrh Spela et al. (1998), Logar Betka (2000), Urankar Janja et al. (2004) and Lukovic (2006).

The effect of the season of successful breeding $(S)$ on the variability of the monitored trait establised in this investigation is in agreement with results reported by Malovrh Spela et al. (1998), Logar Betka (2000), Urankar Janja et al. (2004) and Lukovic (2006).

The same conclusions relevant to the dependance of the NBA on litter gentype $(G L)$ as in this paper were reached by Gajic (1989), Vukovic (2003) and Wolf et al. (2005).

Results obtained for systematic effect of duration of the period from weaning to breeding on the varation of the NBA in this investigation are in agreement with resultats obtained by Betka Logar (2000), Marios et al. (2000), Petrovic Milica et al. (2003), Urankar Janja et al. (2004) and Lukovic (2006).

The effect of sow age, observed as square regression $\left(b_{1}\right.$ and $\left.b_{2}\right)$ nested within farrowing number, was in all cases assessed as a statistically very highly significant $(\mathrm{p}<0.001)$ source of variation of the number of born alive piglets. Obtained results are in agreement with results reported by Urankar Janja et al. (2004) and Lukovic (2006).

In this investigation, the effect of linear regression of duration of 
previous lactation on the variation of the NBA was assessed as statistically very highly significant $(\mathrm{p}<0.001)$ in all cases, except for farm B. Similar conclusions relevant to the effect of this factor on the variation of the monitored trait were presented by Logar Betka (2000), Marios et al. (2000), Urankar Janja (2004) and Lukovic (2006).

Coefficients of model determination presented in Table 2 are very similar to values established by using very similar models for investigating phenotypic variability of the number of born alive piglets by Urankar Janja et al. (2004) and Lukovic (2006). They were in the interval from 0.089 to 0.105 , i.e. from 0.095 to 0.104 , respectively. These values speak in favor of justifying the demonstrated approach for determining and defining the effect in the systematic segment of the model for analyzing the variability of the number of born alive piglets in this paper, since the systematic segment of the model mainly explains a significantly smaller portion of the total variability of this trait (under 10\%).

\title{
Conslusion
}

The phenotypic variability of the NBA established on investigated farms was very pronounced, presenting a good basis for successful selection.

The monitored trait statistically highly significantly $(p<0.001)$ varied under the effect of all systematic factors encompassed by the applied model, regardless of the source of analyzed data. Only the linear regression effect of duration of previous lactation for farm B was assessed as having lower statistical significance $(p<0.05)$. This supports the justification and rationale for applying the indicated model to assess variability of the monitored trait, which is also confirmed by values obtained for model determination coefficients.

\section{FIKSNI DEO MODELA ZA PROCENU PRIPLODNE VREDNOSTI SVINJA NA OSNOVU VELIČINE LEGLA}

\author{
D. Radojković, M. Petrović, M. Mijatović, Č. Radović
}

\section{Rezime}

Cilj ovoga rada bio je da se ispita uticaj različitih sistematskih faktora na 
variranje broja živorođene prasadi u leglu (BŽP) radi određivanja najprilagođenijeg modela za ocenu genetskih parametara i procenu priplodne vrednosti krmača. Analiza fenotipske varijabilnosti BŽP u leglima krmača rase švedski landras sprovedena je na osnovu reproduktivnih pokazatelja 2803 (farma A), 1826 (farma B) i 2235 (farma C) krmača, odnosno njihovih 11014, 6757 i 8452 legala, respektivno. Korišćen je fiksni model metoda najmanjih kvadrata u koga su bili uključeni uticaj prašenja po redu, sezone uspešnog pripusta, genotipa legla, trajanja perioda zalučenje - oplodnja, kvadratni regresijski uticaj starosti krmače pri prašenju ugnježđen u okviru prašenja po redu i linearni regresijski uticaj trajanja prethodne laktacije. Prosečan BŽP se kretao u intervalu od 9.13 (A) do 9.76 (B i C). Svi determinisani uticaji obuhvaćeni modelom su ispoljili statistički vrlo visoko značajan uticaj $(\mathrm{p}<0.001)$ na variranje BŽP nezavisno od toga koji set podataka je bio analiziran, osim uticaja trajanja prethodne laktacije na farmi B koji je bio ocenjen kao statistički značajan $(\mathrm{p}<0.05)$.

Ključne reči: krmače, plodnost, fenotipska varijabilnost

\section{References}

GAJIĆ I. (1989): Karakteristike reproduktivnih osobina svinja u različitim kombinacijama parenja. Stočarstvo, 43, 3-4, 91-102.

JOHANSSON K., KENNEDY B.W. (1985): Estimation of genetic parameters of reproductive traits in pigs. Acta Agriculturae Scandinavica, $35,421-431$.

LOGAR B. (2000): Plemenska vrednost za velikost gnezda pri prašičih v populaciji $\mathrm{z}$ več genetskimi skupinami [Breeding value for litter size in pigs in population with different genetic groups]. Master's thesis. Ljubljana, University of Ljubljana, Biotechnical Faculty, Zootechnical Department, 96 pp.

LUKOVIĆ Z. (2006): Covariance funcions for litter size in pigs using a random regression model. Doctoral Dissertation. Ljubljana, University of Ljubljana, Biotechnical Faculty, Zootechnical Department, 93 pp.

MALOVRH Š., JASENŠEK S., KOVAČ M., ŠTUHEC I. (1998): Influence of season on sow efficiency. In: Proceedings of the 14th International Congress of Biometeorology, Ljubljana, 1996-09-01/08. Ljubljana, $136 \mathrm{pp}$. MARIOS D., BRISBANE J.R., LAFOREST J.P. (2000): Accounting for lactation lenght and weanong-to-conception interval in genetic evaluation for litter size in swine. Journal of Animal Science, 78, 1796-1810. 
PETROVIĆ M., VUKOVIĆ V., RADOJKOVIĆ D., BELIČOVSKI S. (1998): Estimation of breeding value of boars based on fertility of their daughters. Macedonian Agricultural Review, 45, 1-2, 91-94.

PETROVIĆ MILICA, PUŠIĆ M., RADOJKOVIĆ D., ROMIĆ D. (2003): Fenotipska i genetska varijabilnost perioda zalučenje-estrus i zalučenjeoplodnja i njihov uticaj na veličinu narednog legla. VII međunarodni simpozijum "Savremeni trendovi u stočarstvu". Biotehnologija u stočarstvu, 19, 5-6, 229-235.

SAS INST. INC. (2001): The SAS System for Windows, Release 8.02. Cary, NC.

URANKAR J., MALOVRH Š., ULE I., KOVAČ M. (2004): Proučitev komponent variance za velikost gnezda pri prašičih. Spremljanje prizvodnosti prašičev, II del. Univerza v Ljubljani, Biotehniška fakulteta, Katedra za etologijo, biometrijo in slekcije ter prašičerejo, Domžale. str. 7178.

VUKOVIĆ V. (2003): Estimation of genetic parameters for most important reproductive and productive traits of pigs. Doctoral Dissertation. Skopje, University " St. Cyril and Methodius " Faculty of Agriculture, 115 pp.

WOLF J., ŽAKOVA E., GROENEVELD E. (2005): Genetic parameters for a joint genetic evaluation of production and reproduction traits in pigs. Czech Journal of Animal Science, 50 , 3, 96-103. 